\title{
Long-Lasting In Vivo Effects of the Cannabinoid CB1 Antagonist AM6538
}

\author{
Carol A. Paronis, Girish R. Chopda, ${ }^{1}$ Kiran Vemuri, Ani S. Zakarian, Alexandros Makriyannis, \\ and Jack Bergman
}

Center for Drug Discovery (C.A.P., K.V., A.M.) and Department of Pharmaceutical Sciences (C.A.P., G.R.C., A.M.), Northeastern University, Boston, Massachusetts; and Preclinical Pharmacology Program, McLean Hospital, Belmont, Massachusetts (C.A.P., A.S.Z., J.B.)

Received October 10, 2017; accepted January 4, 2018

\begin{abstract}
AM6538 is a cannabinoid antagonist that binds CB1 receptors expressed in HEK-293 cells in a wash-resistant manner. The effects of AM6538 in live animals has not previously been established. We characterized the antagonist effects of AM6538 in male mice, using a warm-water tail-withdrawal assay, and in male squirrel monkeys trained to discriminate the CB1 agonist AM4054 from vehicle. The cannabinoid agonists WIN $55,212, \Delta^{9}$-tetrahydrocannabinol (THC), and AM4054 all produced $100 \%$ maximum possible antinociceptive effects in mice following vehicle pretreatment. One-hour pretreatment with increasing doses of AM6538 $(0.1-10 \mathrm{mg} / \mathrm{kg})$ produced first rightward, then downward shifts of the agonist dose-effect functions. Rimonabant, $1-10 \mathrm{mg} / \mathrm{kg}$, produced parallel rightward shifts of the AM4054 dose-effect functions, and baseline effects
\end{abstract}

of AM4054 were nearly recovered within 24 hours following $10 \mathrm{mg} / \mathrm{kg}$ of rimonabant. In contrast, in mice treated with $10 \mathrm{mg} / \mathrm{kg}$ of AM6538, antagonism of THC or AM4054 lasted up to 7 days. AM6538 also antagonized the discriminative stimulus effects of AM4054 in squirrel monkeys in a doserelated manner, and the effects of $3.2 \mathrm{mg} / \mathrm{kg}$ of AM6538 endured for more than 7 days. The effective reduction in CB1 receptor reserve was used to calculate the relative efficacy (tau values) of WIN 55,212, THC, and AM4054 in mice and of AM4054 monkeys, with results indicating that THC has a lower efficacy than WIN 55,212 or AM4054 in mice. These results demonstrate that AM6538 is a long-acting CB antagonist in vivo, and further suggest that differences in CB efficacy can be revealed in behavioral assays following AM6538 treatment.

\section{Introduction}

Cannabinoids such as marijuana and related plant-based cannabis products (phytocannabinoids) are the most commonly used illicit drugs worldwide (http://www.unodc.org/ wdr2014/). This widespread usage may be attributable, in part, to the acceptance that $\Delta^{9}$-tetrahydrocannabinol (THC), the principal psychoactive constituent of marijuana, is considered relatively safe in comparison with other abused drugs (Nutt et al., 2007). In contrast, newer synthetic cannabinoids have been associated with greater toxicity than phytocannabinoids. The reasons for the different risk profiles of THC and synthetic cannabinoids are not clear. One possible explanation is that the adverse effects of synthetic cannabinoids result from a higher agonist efficacy at cannabinoid $(\mathrm{CB})$ receptors

Portions of this work were presented previously in: Chopda G, Vemuri K, Paronis CA, Makriyannis A, and Bergman J, Possible efficacy related differences among cannabinoid agonists, at the 2013 FASEB meeting in Boston, MA; FASEB J (2013) 27:1097.2.

This work was supported by the National Institutes of Health [Grants DA035411 (to C.A.P.) and DA023142 (to A.M.)]

${ }^{1}$ Current affiliation: Dicerna Pharmaceuticals, Cambridge, Massachusetts https://doi.org/10.1124/jpet.117.245647. than exhibited by THC. As in other drug classes, relatively low efficacy may confer a degree of safety (Liguori et al., 1996), whereas greater toxicity might accompany cannabinoids with higher efficacy.

Through the use of in vitro methods, cannabinoid agonist efficacy has been characterized by equating maximal response with maximal efficacy. For example, studies using assays of forskolin-stimulated cAMP accumulation, $\beta$-arrestin recruitment, GTP $\gamma \mathrm{S}$-binding, or $\mathrm{K}^{+}$channel activation have consistently revealed that older and newer synthetic cannabinoids, including WIN 55,212, CP 55,940, JWH-073, and AB-PINACA have greater efficacy than THC (Govaerts et al., 2004; Brents et al., 2012; Banister et al., 2015). Such differences in maximal agonist effects are less apparent in whole animals, perhaps because most behavioral assays of cannabinoids were developed to identify THC-like effects of novel compounds (Little et al., 1988). Nonetheless, there are some conditions under which THC appears to be a partial agonist in vivo. For example, the dose-effect function for hypothermic effects of THC in Swiss-Webster mice reveals a plateau at approximately $6^{\circ} \mathrm{C}$ below baseline for doses greater than $30 \mathrm{mg} / \mathrm{kg}$ of THC, whereas other cannabinoid agonists are able to decrease

ABBREVIATIONS: AB-PINACA, N-[(1S)-1-(aminocarbonyl)-2-methylpropyl]-1-pentyl-1H-indazole-3-carboxamide; AM4054, 9 $\beta$-(Hydroxymethyl)3-(1-adamantyl)-hexahydrocannabinol; AM6538, 4-(4-(1-(2,4-dichlorophenyl)-4-methyl-3-(piperidin-1-ylcarbamoyl)-1H-pyrazol-5-yl)phenyl)but3-yn-1-yl nitrate; ANOVA, analysis of variance; CB, cannabinoid; HEK, human embryonic kidney; THC, $\Delta^{9}$-tetrahydrocannabinol; WIN 55,212,

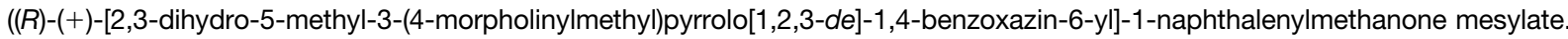


body temperature by $\geq 8^{\circ} \mathrm{C}$ (Paronis et al., 2012; Tai et al., 2015). These relatively limited hypothermic effects have allowed THC to be used as an antagonist of the synthetic cannabinoids AM2389 or JWH-018. In other studies, an indirect approach involving tolerance was used, similar to studies of opioid tolerance that demonstrated the magnitude of tolerance or cross-tolerance varies inversely with agonist efficacy (Paronis and Holtzman, 1992; Walker et al., 1997). Thus, in THC-treated monkeys, greater tolerance is observed to the discriminative stimulus effects of THC than crosstolerance to the THC-like effects of JWH-073, JWH-018, or CP 55,940 , suggesting that THC has lower efficacy than the other three cannabinoid agonists (Hruba et al., 2012). Unfortunately, in vivo studies involving chronic administration to produce tolerance or drug interactions to establish relative agonist/antagonist profiles are time consuming and, hence, are not amenable to assaying a range of compounds simultaneously.

An alternative method of determining agonist efficacy is to quantify the responses to drugs following treatment with irreversible antagonists to inactivate a proportion of the available receptors. According to receptor theory, the shape and position of agonist dose-effect functions following receptor inactivation is dependent on their efficacy: low efficacy agonists do not produce maximal effects following receptor depletion and so their dose-effect functions are shifted downward; in contrast, dose-effect functions of full agonists, which have receptor reserves, are shifted initially to the right and are shifted downward only following higher doses of the antagonist (Furchgott and Bursztyn, 1967). These changes in the agonist dose-effect functions are reflected in differences in the value of the transducer ratio (tau, $\tau$ ), a tissue-dependent measure of the operational efficacy of agonists (Black et al., 1985). One distinct advantage of this approach is that it can be applied in cell-based functional assays, tissue preparations, or whole animals (Leff and Dougall, 1989; Walker et al., 1998; Nickolls et al., 2011). Calculations of tau thus have been used to distinguish full and partial agonists at several different types of receptors (Koek et al., 2000; Madia et al., 2012), and a recent paper described calculation of tau values for two cannabinoid allosteric agonists, in combination with the orthosteric agonist CP 55,940, in human embryonic kidney (HEK)293 cells (Laprairie et al., 2017). To date, however, the method of receptor inactivation has not been used to quantify differences in cannabinoid agonist efficacy in vivo.

A novel structural analog of rimonabant, AM6538, has been described as forming a tight attachment to cannabinoid CB1 receptors (Hua et al., 2016). AM6538 exhibits high affinity for CB1 receptors and competes with CP 55,940 and THC in assays of cAMP inhibition, $\beta$-arrestin recruitment, and GTP $\gamma$ S-binding. However, preincubation of membrane preparations with AM6538 reveal that AM6538 binding is washresistant, suggesting it forms a pseudo-irreversible bond at CB1 receptors. This tight binding ability allows AM6538 to stabilize the CB1 receptor, permitting identification of the crystal structure of modified human $\mathrm{CB} 1$ receptors expressed in HEK293F cells (Hua et al., 2016). In view of this property of AM6538 in vitro, we sought to use AM6538 as a pseudoirreversible antagonist in vivo. The effects of AM6538 pretreatment were examined in an assay of antinociception in mice and a CB1-agonist drug discrimination assay in monkeys. Here, we present findings that AM6538 has long-lasting cannabinoid antagonist effects in mice and nonhuman primates. Further, our data suggest that AM6538 can be used as a tool to delineate the relative efficacies of cannabinoid agonists in vivo.

\section{Materials and Methods}

\section{Antinociception}

Subjects. Male CD-1 mice (Charles River Laboratories, Wilmington, MA) weighing 25-30 g at the start of the study, were housed four per cage in a climate-controlled vivarium with food and water available ad libitum. Prior to testing, mice were habituated by two exposures to handling and the experimental methods described below. All experiments were performed during the light portion of the light/dark cycle. All studies were approved by the Northeastern University Animal Care and Use Committee, in accordance with guidelines established by the National Research Council.

Apparatus and Behavioral Procedure. Antinociception was determined using a warm-water tail-withdrawal assay. A water bath maintained water temperature at $52.0 \pm 0.5^{\circ} \mathrm{C}$. Each mouse was gently hand-held as the distal $2-3 \mathrm{~cm}$ of the tail was immersed in the water; latency to tail-withdrawal was measured using a stopwatch, with a cut-off time of 8 seconds to avoid tissue damage. Baseline latencies were determined twice on each test day with a 10-minute interval between determinations.

Injection Procedures. Complete dose-effect functions for agonists were generated in each mouse in single sessions using cumulative dosing procedures similar to those described previously (Chopda et al., 2016). Briefly, 60 minutes after an injection, tail-withdrawal latencies were determined and, then, mice were injected with the next dose; each injection increased the total cumulative dose by $0.5 \mathrm{log}$ units. This procedure was repeated until the tail-withdrawal latency reached the cut-off or no longer increased with subsequent increases in drug dose. Pilot studies with $3 \mathrm{mg} / \mathrm{kg}$ AM6538 indicated that antagonism of AM4054 occurred in less than 30 minutes but reached maximum effects at 1-2 hours after injection. Thus, agonist doseeffect functions were initially determined 60 minutes after injection with vehicle or with graded doses of AM6538 or rimonabant. To assess the time course of antagonism, effects of AM4054 or THC were redetermined in sessions that began at various times, ranging from 1 to 7 days, after injection of $10 \mathrm{mg} / \mathrm{kg}$ of AM6538 or rimonabant. Each mouse was tested once or twice, with at least 1 week between test sessions.

\section{AM4054 Discriminative Stimulus Effects}

Subjects. Six adult male squirrel monkeys (Saimiri sciureus) were used in the procedures described here. Experimental sessions were conducted 5 days a week (Monday-Friday). The experimental protocol for the present studies was approved by the Institutional Animal Care and Use Committee at McLean Hospital. Subjects were maintained in a facility licensed by the U.S. Department of Agriculture and in accordance with the guidelines established by the National Research Council.

Apparatus. During experimental sessions, subjects sat in a Plexiglas chair within a ventilated sound- and light-attenuating chamber as described previously (Delatte and Paronis, 2008). The front panel of the chair was outfitted with two response levers that were positioned $6 \mathrm{~cm}$ left and right of center. Each lever-press with a force of at least $0.25 \mathrm{~N}$ closed a microswitch, produced an audible click, and was recorded as a response. Red stimulus lights were mounted behind the transparent front panel of the chair, approximately $10 \mathrm{~cm}$ above each response lever. Before each session, a shaved portion of each subject's tail was coated with electrode paste and placed under brass electrodes for the delivery of brief, low-intensity current (see below). Experimental events and data collection were controlled by 
interfacing equipment and operating software from Med Associates (St. Albans, VT).

Behavioral Procedure. The subjects were previously trained to discriminate the pre-session administration of $0.01 \mathrm{mg} / \mathrm{kg}$ of the cannabinoid agonist AM4054 or its vehicle by responding on one of two levers. Briefly, subjects initially were trained to terminate visual stimuli associated with the delivery of brief, low-intensity current (200 milliseconds; $3 \mathrm{~mA}$ ) across the electrodes by depressing one of the two response levers. The active lever varied until subjects reliably terminated visual stimuli by responding on either lever. Subsequently, both levers were present in all sessions and the active lever was signaled only by a pre-session injection: One lever was active only following the intramuscular injection of the CB1 agonist AM4054 $(0.01 \mathrm{mg} / \mathrm{kg}$, i.m.), and the other lever was active only following intramuscular injection of vehicle; right- and left-lever assignments were counterbalanced among subjects. Following initial training, each subsequent session began with a 30 -minute timeout period during which all lights were extinguished and responding had no programmed consequences. After the timeout period, two red stimulus lights above each lever were illuminated and completion of 10 consecutive responses [fixed ratio (FR) 10] on the active lever extinguished all stimulus lights and initiated a 50-second timeout. Responses on the inactive lever reset the FR requirement. Current was scheduled for delivery every 10 seconds until either the FR 10 was completed on the correct lever or 30 seconds elapsed, whichever came first.

Drug Testing. Tests for generalization of AM4054 to the training stimulus were conducted when a subject's discrimination performance was at least $90 \%$ accurate for four of the last five training sessions and on the immediately preceding session. Procedurally, test sessions differed from training sessions in two ways. First, 10 consecutive responses on either lever extinguished the stimulus lights and associated current delivery, and initiated the 50-second timeout. Second, no current deliveries were scheduled during test sessions so as to preclude possible stimulus-induced enhancement of responding. Other schedule contingencies were unchanged. Using cumulativedosing procedures, graded doses of AM4054 were administered at the beginning of sequential components of the test session (i.e., at the onset of the 30-minute timeout periods that initiated session components). Test sessions began at various times, 1 hour to 7 days, after injection of AM6538.

Drugs. $\Delta^{9}$-THC and rimonabant were obtained from the National Institute on Drug Abuse (NIDA; Rockville, MD]; WIN-55-212 [(R)-(+ )-[2,3-dihydro-5-methyl-3-(4-morpholinylmethyl)pyrrolo[1,2,3-de]-1,4benzoxazin-6-yl]-1-naphthalenylmethanone mesylate] was purchased from Sigma-Aldrich (St. Louis, MO). AM4054 [9 $\beta$-(hydroxymethyl)-3(1-adamantyl)-hexahydrocannabinol] and AM6538 [4-(4-(1-(2,4-dichlorophenyl)-4-methyl-3-(piperidin-1-ylcarbamoyl)- $1 H$-pyrazol-5-yl) phenyl)but-3-yn-1-yl nitrate] were synthesized at the Center for Drug Discovery, Northeastern University. All compounds were prepared in 5\% ethanol, 5\% emulphor-620 (Rhodia, Cranbury, NJ), and 90\% saline, and further diluted with saline. Drug doses are expressed in terms of the weight of free base.

Measurement of Effects and Statistical Analysis. Tail withdrawal latencies are expressed as a percentage of maximum possible effect (\%MPE \pm S.E.M.), calculated using the formula: $\%$ MPE $=[$ (test latency - baseline latency $) /(8-$ baseline latency $)] \times 100$. The two primary dependent measures in discrimination studies are response distribution across the two levers and overall response rate. Response distribution (\% AM4054 lever responses) was calculated by dividing the number of responses on the lever associated with the injection of AM4054 by the total number of responses (excluding any responses during timeout periods). Response rate was calculated by dividing the total number of responses on both levers by the total session time (excluding all timeout periods). Doses of drugs were considered to substitute fully when response distribution was 90\% AM4054 lever and response rates were sufficiently high $(>0.2$ responses/s) to calculate a meaningful response distribution values. Data were plotted and analyzed with doses expressed as log-transformed values using GraphPad Prism v. 5.02 (GraphPad Software, San Diego, CA) to obtain $\mathrm{ED}_{50}$ and tau values along with $95 \% \mathrm{CI}$; values were considered to be different if there was no overlap of the $95 \%$ CI. Nonlinear regression analysis of grouped data, applying constant values for maximum (100\%) and minimum (0\%) effects, were used to calculate $\mathrm{ED}_{50}$ values of the agonists. Mean dose-effect functions for each agonist were simultaneously fit to the operational model for agonism to obtain tau values for each curve, by applying common values for slope and $K_{\mathrm{A}}$ and constant values for maximum (100\%) and minimum $(0 \%)$ effects. The fraction of available receptors remaining was calculated as the ratio of tau values before and after AM6538 treatment. Response rates obtained for each dose-response function were analyzed using one-way analysis of variance (ANOVA), followed by Dunnett's multiple comparison test, comparing data from each dose to response rates obtained after saline and $0.1 \mathrm{mg} / \mathrm{kg}$ AM4054 during training sessions; significance for all tests was set at $P<0.05$.

\section{Results}

\section{Antinociception}

Control Values. AM6538 did not alter the latency to tailwithdrawal responses, whereas AM4054, THC, and WIN 55,212 produced near maximal antinociceptive effects. Baseline tail-flick latencies in vehicle-treated mice averaged 2.1 seconds, and ranged from 1.4 to 2.7 seconds. One hour after pretreatment with $0.1,0.3,3.0$, or $10 \mathrm{mg} / \mathrm{kg}$ AM6538, average tail-flick latencies were unchanged $(2.0,2.1,2.0$, and 2.2 seconds, respectively). Cumulative injections of AM4054 dose-dependently increased tail-flick latencies in vehiclepretreated animals, with an $\mathrm{ED}_{50}$ value of $0.38 \mathrm{mg} / \mathrm{kg}$ (see Table 1). THC and WIN 55,212 had effects that were qualitatively similar to AM4054, but with lesser potency. The control $\mathrm{ED}_{50}$ values were $18.2 \mathrm{mg} / \mathrm{kg}$ for $\mathrm{THC}$ and $2.8 \mathrm{mg} / \mathrm{kg}$ for WIN 55,212 .

Antagonist Effects of AM6538. One-hour pretreatment with AM6538 dose-dependently antagonized the antinociceptive effects of AM4054. As shown in Fig. 1A, the dose of $0.3 \mathrm{mg} / \mathrm{kg}$ AM6538 produced a rightward shift in the AM4054 dose-effect function, increasing the $\mathrm{ED}_{50}$ to 0.56 , and $3 \mathrm{mg} / \mathrm{kg}$ $\mathrm{AM} 6538$ further increased the $\mathrm{ED}_{50}$ value to $2.47 \mathrm{mg} / \mathrm{kg}$, significantly different from the control $\mathrm{ED}_{50}$ value (see Table 1). The dose of $10 \mathrm{mg} / \mathrm{kg}$ AM6538 decreased the maximum obtained effect, resulting in a flattening of the AM4054 dose-effect function. Also in Fig. 1, AM6538 similarly antagonized the antinociceptive effects of WIN 55,212. The dose of $0.3 \mathrm{mg} / \mathrm{kg}$ AM6538 increased the $\mathrm{ED}_{50}$ of WIN 55,212 to $4.0 \mathrm{mg} / \mathrm{kg}$ and after pretreatment with $3.0 \mathrm{mg} / \mathrm{kg}$ AM6538, a dose of $100 \mathrm{mg} / \mathrm{kg}$ WIN 55,212 resulted in only $71 \%$ of the maximum possible antinociceptive effect and significantly increasing the $\mathrm{ED}_{50}$ value (Table 1). AM6538 was more potent in antagonizing the effects of THC (Fig. 1B). The doses of 0.3, 3.0 , and $10 \mathrm{mg} / \mathrm{kg}$ all flattened the THC dose-effect function, and $300 \mathrm{mg} / \mathrm{kg}$ THC produced less than $50 \%$ of the maximum possible effect, precluding the determination of $\mathrm{ED}_{50}$ values. A lower dose of $0.1 \mathrm{mg} / \mathrm{kg}$ AM6538 marginally (less than 2-fold) increased the $\mathrm{ED}_{50}$ of $\mathrm{THC}$ to $31.4 \mathrm{mg} / \mathrm{kg}$.

AM6538 Time Course. Figure 2 depicts the recovery of the antinociceptive effects of THC and AM4054 at different times following treatment with $10 \mathrm{mg} / \mathrm{kg}$ AM6538. Antagonism of AM4054 by AM6538 was greatest 1 hour after injection; the dose of $10 \mathrm{mg} / \mathrm{kg}$ AM4054 yielded only $37 \pm$ $11 \%$ of the maximum possible effect. At 24-48 hours after injection of AM6538, there was some recovery in the effects of 
TABLE 1

$\mathrm{ED}_{50}$ values in milligrams per kilogram (with 95\% CI) obtained in the mouse antinociception assay following 1-hour pretreatment with AM6538

\begin{tabular}{lccc}
\hline \multirow{2}{*}{ AM6538 Pretreatment } & \multicolumn{3}{c}{ Agonist } \\
\cline { 2 - 4 } & THC & WIN 55,212 & AM4054 \\
\hline Control & $18.2(11.9,27.8)$ & $2.8(1.9,4.4)$ & $0.38(0.29,0.50)$ \\
$0.1 \mathrm{mg} / \mathrm{kg}$ & $31.4(16.1,61.2)$ & $--^{a}$ & $--^{b}$ \\
$0.3 \mathrm{mg} / \mathrm{kg}$ & $>300^{b}$ & $4.0(2.4,6.7)$ & $0.56(0.36,0.87)$ \\
$3 \mathrm{mg} / \mathrm{kg}$ & $>300^{b}$ & $18.0^{c}(8.1,40.4)$ & $2.47^{c}(1.18,5.21)$ \\
\hline
\end{tabular}

${ }^{a}$ Not determined.

${ }^{b}$ Maximum obtained effect $<50 \%, \mathrm{ED}_{50}$ value not calculated.

${ }^{c}$ Different from control value $(P<0.05)$.

AM4054: $10 \mathrm{mg} / \mathrm{kg}$ AM4054 produced nearly full antinociceptive effects, though this represented a significant rightward shift of the AM4054 dose-effect function (Fig. 2A). The $\mathrm{ED}_{50}$ of AM4054 at 24 hours after AM6538 was $2.46 \mathrm{mg} / \mathrm{kg}$, slightly more than $3 / 4$ of a log unit to the right of the control function, and at 48 hours after AM6538 the AM4054 $\mathrm{ED}_{50}$ was still significantly greater than the control value (see Table 2). Baseline effects of AM4054 were fully recovered by 7 days after the AM6538 injection, with an $\mathrm{ED}_{50}$ value of $0.25 \mathrm{mg} / \mathrm{kg}$.

As shown in Fig. 2B, a similar pattern of recovery was obtained with THC: at 48 hours after AM $6538,300 \mathrm{mg} / \mathrm{kg}$ THC produced approximately $60 \%$ of the maximum possible antinociceptive effects, and the $\mathrm{ED}_{50}$ value of $\mathrm{THC}$ was $197 \mathrm{mg} / \mathrm{kg}$, reflecting an approximately 1 log-unit rightward shift of the dose-effect function. Seven days after treatment with
AM6538, $100 \mathrm{mg} / \mathrm{kg}$ of THC produced $73 \pm 8 \%$ of the maximum possible antinociceptive effect, and the THC $\mathrm{ED}_{50}$ was $32.3 \mathrm{mg} / \mathrm{kg}$ (Table 2).

Rimonabant Antagonism. The effects of AM4054 were also determined following treatment with $1-10 \mathrm{mg} / \mathrm{kg}$ of rimonabant, with results shown in Fig. 3A. Rimonabant produced a surmountable rightward shift in the AM4054 dose-effect function. In these studies, the $\mathrm{ED}_{50}$ of AM4054 under control conditions (i.e., 30 minutes after vehicle pretreatment) was $0.30 \mathrm{mg} / \mathrm{kg}(0.23,0.38)$. Following treatment with 1 and $3 \mathrm{mg} / \mathrm{kg}$ of rimonabant, the $\mathrm{AM} 4054 \mathrm{ED}_{50}$ was increased to, respectively, $0.42(0.32,0.55)$ and $0.63 \mathrm{mg} / \mathrm{kg}$ $(0.44,0.90)$. The dose of $10 \mathrm{mg} / \mathrm{kg}$ of rimonabant produced a 10-fold shift in the AM4054 dose-effect function, with an $\mathrm{ED}_{50}$ of $3.04 \mathrm{mg} / \mathrm{kg}(2.23,4.13)$. As depicted in Fig. 3B, there was
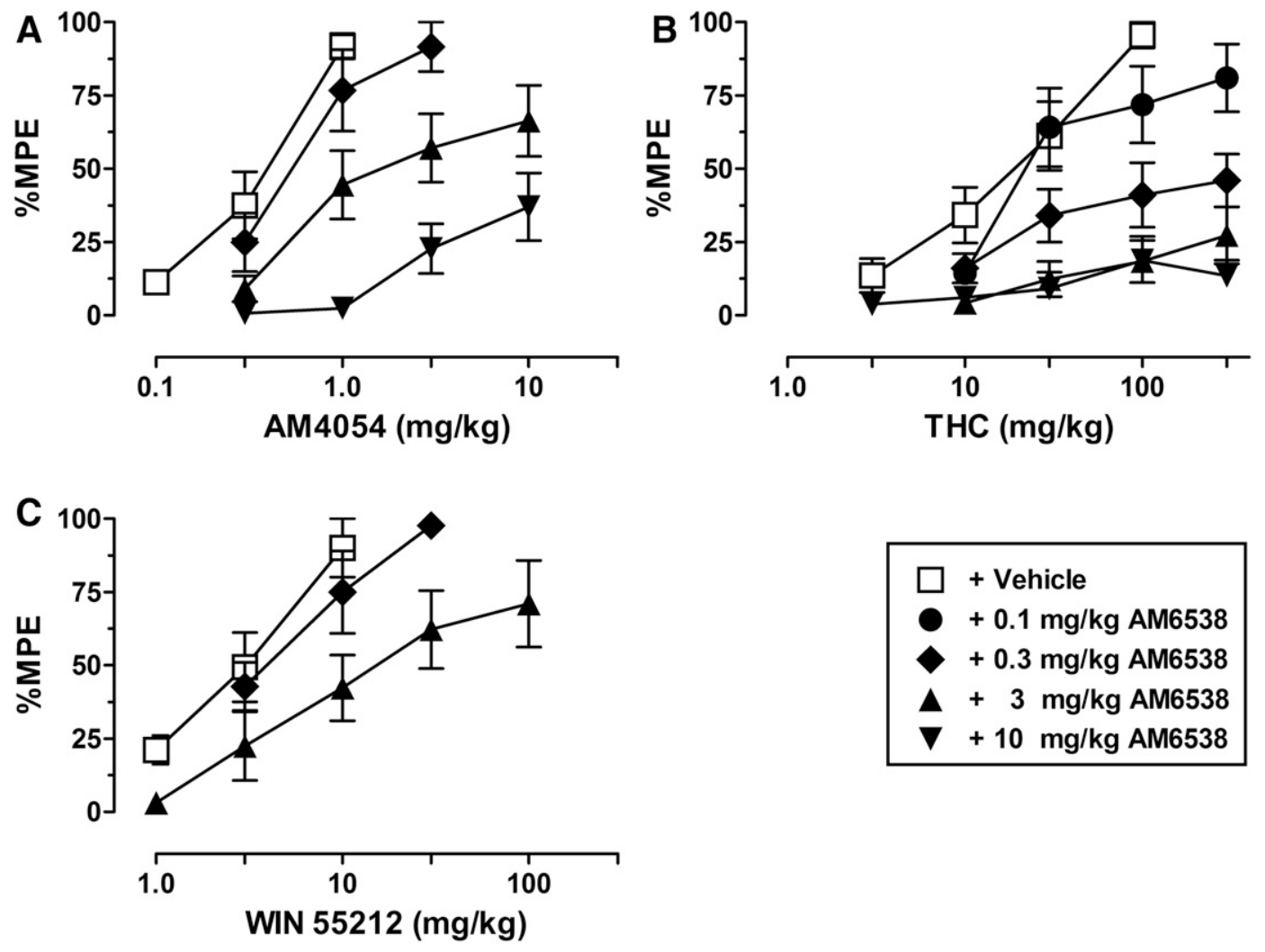

Fig. 1. AM6538 antagonizes the antinociceptive effects of cannabinoid agonists in mice. (A) Effects of AM4054 after 1 hour pretreatment with vehicle or $0.3-10.0 \mathrm{mg} / \mathrm{kg}$ of AM6538; (B) Effects of THC after 1 hour pretreatment with vehicle or $0.1-3.0 \mathrm{mg} / \mathrm{kg}$ of AM6538; (C) Effects of WIN 55,212 after 1 hour pretreatment with vehicle or 0.3 or $3.0 \mathrm{mg} / \mathrm{kg}$ of AM6538. Each point represents the mean of six to eight mice; vertical bars indicate \pm S.E.M. Ordinates, percent of maximal antinociceptive effect; abscissae, cumulative drug dose in milligrams per kilogram. 


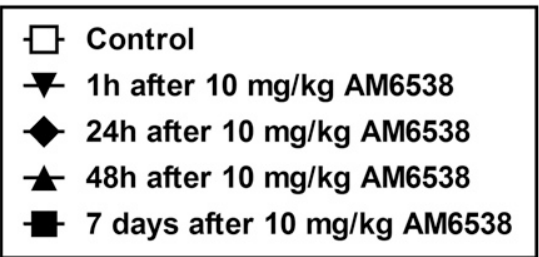

A

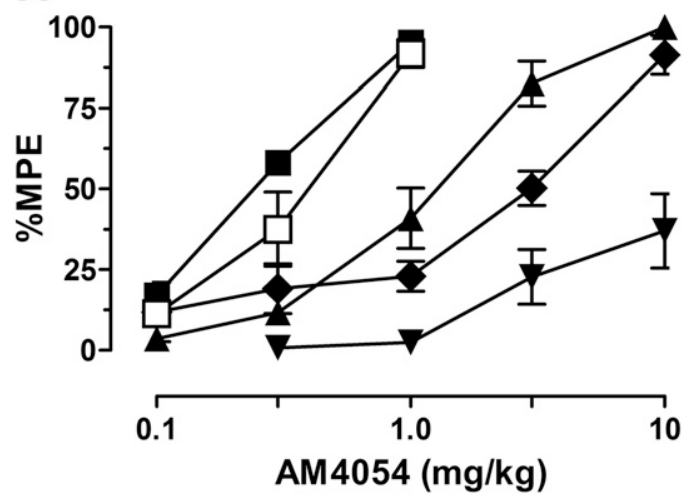

B

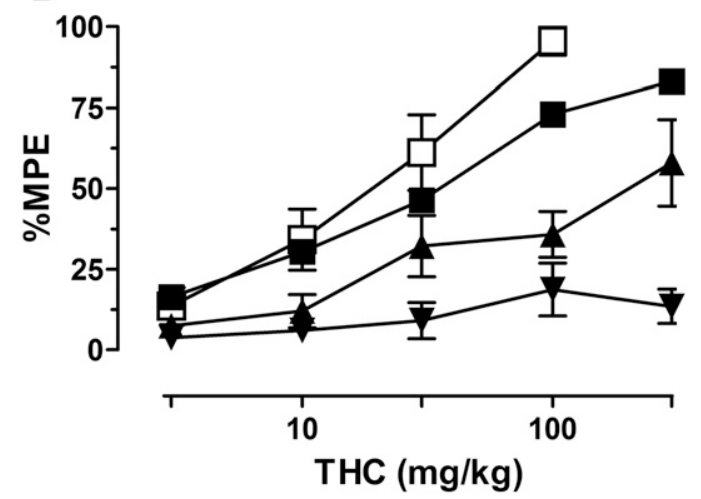

Fig. 2. Antagonism of the antinociceptive effects of AM4054 (A) or THC (B) 1 hour after administration of vehicle (open symbols) or at different times, 1 hour to 7 days, after administration of $10 \mathrm{mg} / \mathrm{kg}$ of AM6538 in mice; other details as in Fig. 1. Data in vehicle-treated animals and 1 hour after AM6538 are replotted from Fig. 1 to facilitate comparison.

nearly full recovery of AM4054's effects from this dose of rimonabant within 24 hours, with an $\mathrm{ED}_{50}$ value of $0.44 \mathrm{mg} / \mathrm{kg}$ $(0.32,0.60)$.

\section{Drug Discrimination}

Control Values. During the training days preceding test days, squirrel monkeys responded nearly exclusively on the vehicle lever during vehicle training cycles and nearly exclusively on the drug lever during AM4054 training cycles. Mean response rates $\left( \pm\right.$ S.E.M.) did not differ $\left(t_{(5)}=0.16\right)$ during vehicle and AM4054 training cycles and were $3.26( \pm 0.40)$ and $3.19( \pm 0.41)$ responses/s, respectively. As shown in Fig. 4, cumulative injections of AM4054, $0.001-0.01 \mathrm{mg} / \mathrm{kg}$, produced dose-related increases in responding on the AM4054associated lever without altering response rates $\left(\mathrm{F}_{(4,25)}=\right.$ 0.50 ). Full substitution ( $\geq 90 \%$ responding on the drug lever) occurred following cumulative injection of the training dose of $0.01 \mathrm{mg} / \mathrm{kg}$ of $\mathrm{AM} 4054$, and the group average $\mathrm{ED}_{50}$ was $0.004 \mathrm{mg} / \mathrm{kg}(0.002,0.008)$.

Antagonist Effects of AM6538. In initial experiments, monkeys received 1 or $3 \mathrm{mg} / \mathrm{kg}$ of AM6538 1 hour prior to test sessions in which the dose-effect function of AM4054 was redetermined. As seen in Fig. 4, both doses of AM6538 antagonized the effects of AM4054, resulting in significant rightward shifts of the dose-effect function with no decrease in the maximum effects. Following $1 \mathrm{mg} / \mathrm{kg}$ of AM6538, the $\mathrm{ED}_{50}$ of AM4054 was increased more than 6 -fold to $0.025 \mathrm{mg} / \mathrm{kg}$ $(0.018,0.036)$ and after $3 \mathrm{mg} / \mathrm{kg}$ of $\mathrm{AM} 6538$ the $\mathrm{ED}_{50}$ value was $0.24 \mathrm{mg} / \mathrm{kg}(0.13,0.44)$ or 60 -fold higher than the control value. A one-way ANOVA revealed significant differences in response rates $\left(\mathrm{F}_{(12,48)}=2.128 ; P=0.0324\right)$; however post-hoc analysis identified no differences from control values obtained with saline or $0.01 \mathrm{mg} / \mathrm{kg}$ of AM4054.
AM6538 Time Course. Figure 5 shows the duration of antagonism following $3 \mathrm{mg} / \mathrm{kg}$ of AM6538. As was seen with antinociceptive effects in mice, the antagonism of the discriminative stimulus effects of AM4054 effects was greatest 1 hour after injection of AM6538 followed by a gradual recovery toward control over the 7 days of testing. Thus, significant antagonism was apparent at 2 and 4 days after AM6538, and there was still a slight rightward shift in the AM 4054 doseeffect function (more than 2-fold) at 7 days. The $\mathrm{ED}_{50}$ values of AM4054 at the different times are as follows: $0.033 \mathrm{mg} / \mathrm{kg}$ $(0.016,0.067)$ at 2 days, $0.015 \mathrm{mg} / \mathrm{kg}(0.008,0.026)$ at 4 days, and $0.009 \mathrm{mg} / \mathrm{kg}(0.006,0.014)$ at 7 days after $3 \mathrm{mg} / \mathrm{kg}$ of AM6538. A one-way ANOVA revealed no differences in response rates $\left(\mathrm{F}_{(18,70)}=1.202 ; P=0.28\right)$.

Agonist Efficacy. Tables 3 and 4 present tau values calculated for THC, WIN 55,212, and AM4054; these values were used to estimate the fraction of available receptors remaining after AM6538 treatment. The top row in Table 3 lists initial tau values for THC, WIN 55,212, and AM4054; in

\section{TABLE 2}

THC and AM4054 $\mathrm{ED}_{50}$ values in milligrams per kilogram (with 95\% CI) obtained in the mouse antinociception assay at various times after pretreatment with $10 \mathrm{mg} / \mathrm{kg}$ of AM6538

\begin{tabular}{|c|c|c|}
\hline \multirow{2}{*}{ Time after $10 \mathrm{mg} / \mathrm{kg}$ of AM6538 } & \multicolumn{2}{|c|}{ Agonist } \\
\hline & THC & AM4054 \\
\hline $1 \mathrm{~h}$ & $>300^{a}$ & $>10^{a}$ \\
\hline $24 \mathrm{~h}$ & $-b$ & $2.46^{c}(1.69,3.58)$ \\
\hline $48 \mathrm{~h}$ & $196.8^{c}(85.8,451.6)$ & $1.22^{c}(0.98,1.51)$ \\
\hline 7 day & $32.3(19.6,53.2)$ & $0.25(0.20,0.33)$ \\
\hline
\end{tabular}

${ }^{a}$ Maximum obtained effect $<50 \%, \mathrm{ED}_{50}$ value not calculated.

${ }^{b}$ Not determined.

${ }^{c}$ Different from control value presented in Table $1(P<0.05)$. 

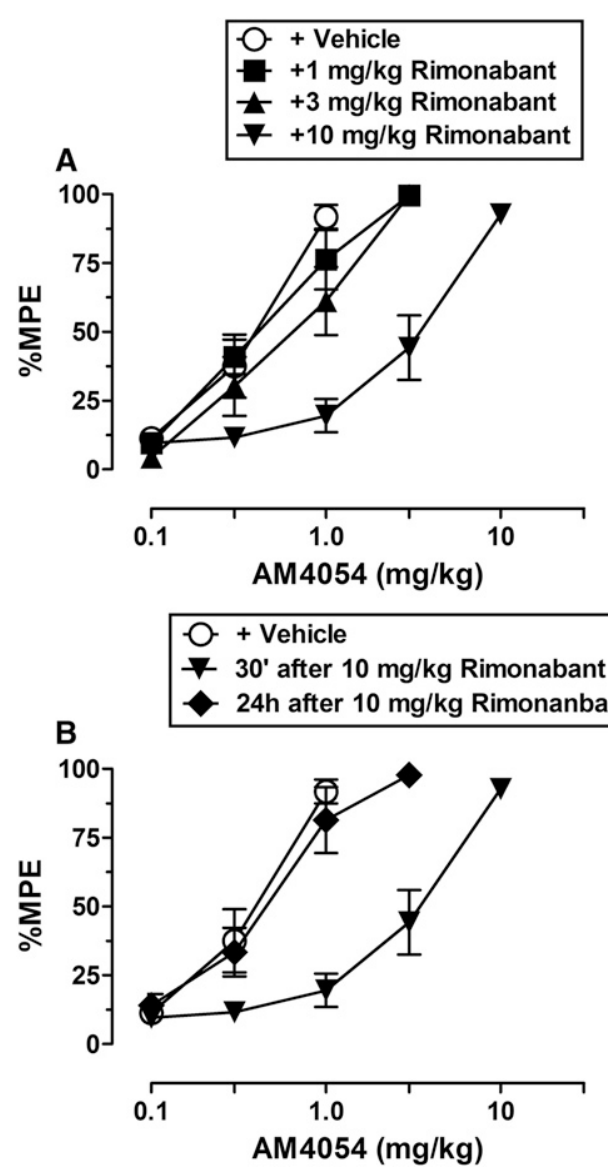

Fig. 3. Antagonism of the antinociceptive effects of AM4054 by rimonabant in mice. (A) Effects of AM4054 after 30-minute pretreatment with $1-10 \mathrm{mg} / \mathrm{kg}$ of rimonabant; (B) effects of AM4054 after 30-minute pretreatment with vehicle or 30-minute or 24-hour pretreatment with $10 \mathrm{mg} / \mathrm{kg}$ of rimonabant; other details as in Fig. 1.

antinociception studies, these values were not significantly different. AM6538 dose dependently decreased the tau values for all cannabinoid agonists, reflecting reductions in the available receptors. Following $0.3 \mathrm{mg} / \mathrm{kg}$ of AM6538, the tau value for THC was decreased to 1.3, indicating the fraction of receptors that remained available was $27 \%$, whereas for WIN 55,212 and AM4054 the fraction of available receptors was reduced to 78 and $72 \%$ of control levels, respectively. The higher dose of $3.0 \mathrm{mg} / \mathrm{kg}$ of AM6538 resulted in $12 \%$ of receptors remaining for THC, and 31 and $27 \%$ for WIN 55,212 and AM4054, respectively. The initial tau value for AM4054 in the squirrel monkey discrimination studies was higher than those obtained for any of the cannabinoid agonists in mice, yet also was highly susceptible to reduction by AM6538: The fraction of remaining receptors was $18 \%$ after treatment with $1 \mathrm{mg} / \mathrm{kg}$ of AM6538 and was further reduced to $4 \%$ after $3 \mathrm{mg} / \mathrm{kg}$.

Table 4 presents tau values for THC and AM4054 at different times after $10 \mathrm{mg} / \mathrm{kg}$ of AM6538 in antinociceptive studies in mice, and for AM4054 after $3 \mathrm{mg} / \mathrm{kg}$ of AM6538 in drug discrimination studies in monkeys. The dose of $10 \mathrm{mg} / \mathrm{kg}$ of AM6538 initially reduced the tau value of THC to 0.4, indicating only $9 \%$ of available receptors remained; these values increased to $29 \%$ at 48 hours and $69 \%$ at 7 days following the administration of $10 \mathrm{mg} / \mathrm{kg}$ of AM6538. The tau
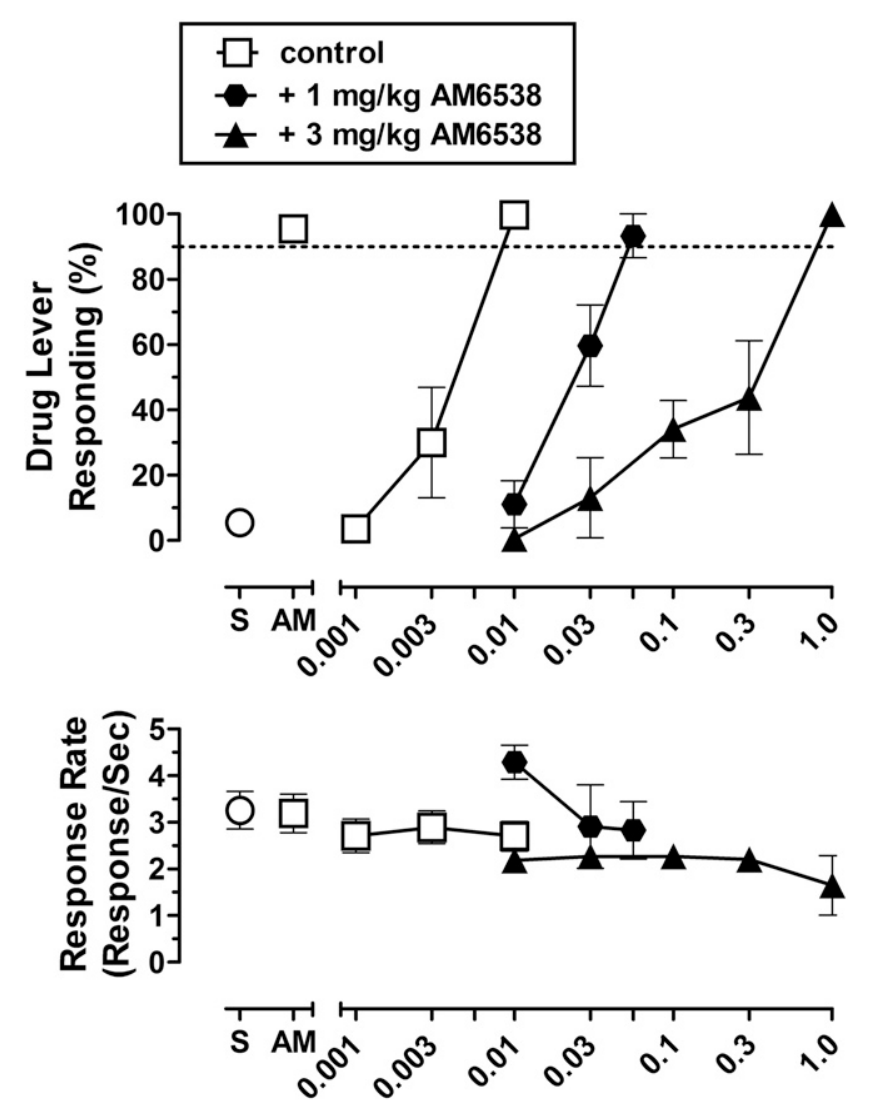

AM4054 (mg/kg)

Fig. 4. Discriminative stimulus effects of AM4054 in squirrel monkeys alone or 1 hour after pretreatment with 1 or $3 \mathrm{mg} / \mathrm{kg}$ of AM6538. Each point represents the mean of three to six monkeys; vertical bars indicate \pm S.E.M. Ordinates: (top) percent responding on the AM4054-associated lever; (bottom): response rates expressed as responses per second. Abscissae: cumulative drug dose in milligrams per kilogram body weight; points above "S" and "AM" show control data from saline and $0.01 \mathrm{mg} / \mathrm{kg}$ of AM4054 training cycles, respectively.

values for AM4054 also increased progressively over time. In mice, the dose of $10 \mathrm{mg} / \mathrm{kg}$ of AM6538 yielded a tau value for AM4054 of 1.0, reflecting $10 \%$ of receptors remained available, and this increased to 25 and $41 \%$ at 24 and 48 hours after AM6538, respectively. Full recovery occurred 7 days after AM6538 and, possibly, even a slight overshoot occurred, as the tau value of 14.6 reflected $145 \%$ of the baseline receptor availability. The AM4054 tau values obtained in squirrel monkeys also increased over time, and the fraction of available receptors at 48 hours and 7 days were 14 and $46 \%$, respectively.

\section{Discussion}

The three cannabinoid agonists tested-THC, WIN 55,212, and AM4054-all produced maximum antinociception in mice when warm water was used as the nociceptive stimulus. Previous studies have shown that the antinociceptive effects of THC and WIN 55,212 are antagonized by rimonabant, consistent with CB1-receptor mediation (Rinaldi-Carmona et al., 1994; Marshell et al., 2014). The antagonism of AM4054-induced antinociception by rimonabant in the present studies confirm that these effects are also probably 

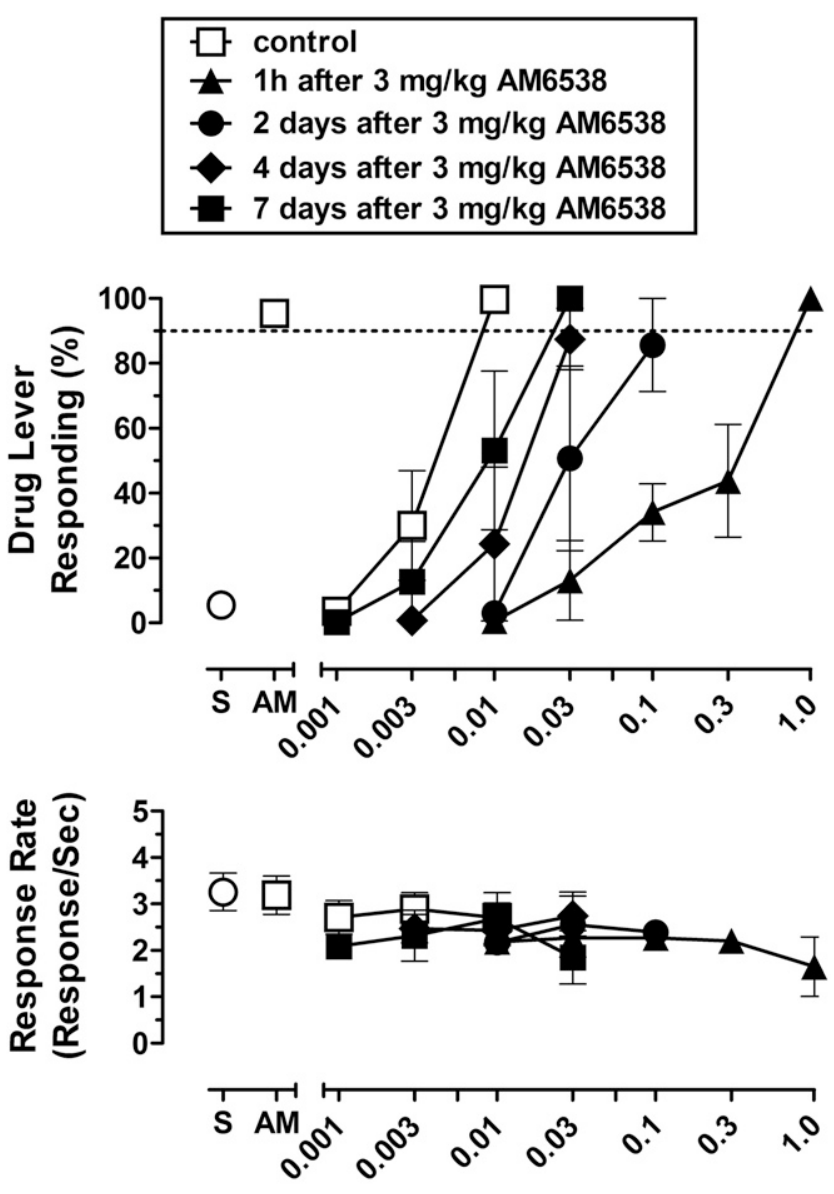

AM4054 (mg/kg)

Fig. 5. Discriminative stimulus effects of AM4054 at different times, 1 hour to 7 days, after administration of $3 \mathrm{mg} / \mathrm{kg}$ of AM6538 in monkeys; other details as in Fig. 4. Data in vehicle-treated animals and 1 hour after AM6538 are the same as those presented in Fig. 4.

CB1-receptor mediated. As expected for a competitive antagonist, rimonabant pretreatment resulted in surmountable rightward shifts of the AM4054 dose-effect function. There were some lingering antagonist effects of the highest dose of rimonabant tested, $10 \mathrm{mg} / \mathrm{kg}$, at 24 hours after injection, but these effects were small. These results are in keeping with previous characterizations of the pharmacokinetic profile of rimonabant in mice (Rinaldi-Carmona et al., 1994; Petitet et al., 1999).

Like rimonabant, AM6538 also dose dependently antagonized the antinociceptive effects of the three cannabinoid agonists in mice. Lower pretreatment doses of AM6538 produced relatively modest rightward shifts of the agonist doeseffect functions, whereas higher AM6538 doses produced larger rightward shifts and decreased the maximum effect of each agonist. Moreover, AM6538 produced enduring antagonism, with robust effects on the THC dose-effect function evident up to 7 days after treatment.

The effects of AM4054 were further studied in a drug discrimination assay in squirrel monkeys. Previous studies from this laboratory have demonstrated that these effects of AM4054 are CB1-receptor mediated in squirrel monkeys (Kangas et al., 2013). As was seen in the antinociception studies, AM6538 also dose dependently shifted the dose-effect function for the discriminative stimulus effects of AM4054 rightward, and these effects persisted for at least 4-7 days. Taken together, our results in male subjects demonstrate that AM6538 can be an effective long-acting cannabinoid antagonist in vivo, across different types of behavioral assays and in different species.

AM6538 is a structural analog of rimonabant that was developed as a ligand capable of stabilizing the CB1 receptor. Functional in vitro studies recently revealed that the interaction between CP 55,940 and AM6538 is competitive when the ligands are coadministered, yet preincubation of CB1 receptors with AM6538 results in wash-resistant binding, suggesting that it forms noncovalent, but tight, attachments with cannabinoid CB1 receptors (Hua et al., 2016). Although the chemical nature of this interaction remains to be determined, the long duration of action and decreases in maximal agonist effects reported here in AM6538-treated animals is consistent with the conclusion that AM6538 acts as a pseudo-irreversible CB1 receptor antagonist in vivo.

Receptor elimination has been used in the past to identify receptor mechanisms of particular drug responses, to isolate receptors of interest, and to characterize drug efficacy. Advances in genetic disruption have led to increased use of transgenic mice to address these issues, no doubt owing to the selectivity afforded by gene targeting, as well as the possibility of complete elimination of the receptor in question (Rohrer and Kobilka, 1998). Nonetheless, pharmacological manipulation of receptor number has distinct advantages, namely the ability to use graded doses to produce graded effects and, of translational value, cross-species verification of effect. We took advantage of these properties to determine the relative efficacy of different cannabinoid agonists in mice, and for a single agonist in two species.

Apparent agonist efficacy was quantified by obtaining tau values using the operational model of receptor function

TABLE 3

Tau values (with 95\% CI) obtained 1 hour after AM6538 in mice (antinociception) or monkeys (drug discrimination)

\begin{tabular}{|c|c|c|c|c|}
\hline \multirow{2}{*}{ AM6538 Pretreatment } & \multicolumn{4}{|c|}{ Agonist } \\
\hline & THC (Mouse) & WIN 55,212 (Mouse) & AM4054 (Mouse) & AM4054 (Monkey) \\
\hline Control & $4.6(1.6,13.6)$ & $6.8(1.3,35.0)$ & $10.1(2.4,42.8)$ & $60.1(10.8,333.6)$ \\
\hline $0.1 \mathrm{mg} / \mathrm{kg}$ & $3.2(1.3,7.9)$ & $-a$ & $-{ }_{a}$ & ${ }_{a}$ \\
\hline $0.3 \mathrm{mg} / \mathrm{kg}$ & $1.3(0.8,2.0)$ & $5.4(1.1,26.0)$ & $7.3(1.8,28.9)$ & $-^{a}$ \\
\hline $1 \mathrm{mg} / \mathrm{kg}$ & $1.0\left(\begin{array}{c}0.0,2.0) \\
-\end{array}\right.$ & $\underline{-}_{a}$ & ]$_{a}$ & $10.7(2 . \overline{1}, 54.6)$ \\
\hline $3 \mathrm{mg} / \mathrm{kg}$ & $0.6^{b}(0.4,0.9)$ & $2.1^{b}(0.9,5.4)$ & $2.7(1.1,7.0)$ & $2.2^{b}(0.9,5.4)$ \\
\hline $10 \mathrm{mg} / \mathrm{kg}$ & $0.4^{b}(0.2,0.7)$ & $-a$ & $1.0^{b}(0.6,1.7)$ & $-a$ \\
\hline
\end{tabular}

${ }^{a}$ Not determined.

${ }^{b}$ Different from control value $(P<0.05)$. 
TABLE 4

Tau values (with 95\% CI) obtained at different times after $10 \mathrm{mg} / \mathrm{kg}$ of AM6538 in mice (antinociception) or $3 \mathrm{mg} / \mathrm{kg}$ of AM6538 in monkeys (drug discrimination)

\begin{tabular}{|c|c|c|c|}
\hline \multirow{3}{*}{ Time after AM6538 } & \multicolumn{3}{|c|}{ Agonist } \\
\hline & THC (Mouse) & AM4054 (Mouse) & \multirow{2}{*}{$\begin{array}{l}\text { AM4054 (Monkey) } \\
3 \mathrm{mg} / \mathrm{kg} \text { of AM6538 }\end{array}$} \\
\hline & \multicolumn{2}{|c|}{$10 \mathrm{mg} / \mathrm{kg}$ of AM6538 } & \\
\hline Control & $4.6(1.6,13.6)$ & $10.1(2.4,42.8)$ & $60.1(10.8,333.6)$ \\
\hline $1 \mathrm{~h}$ & $0.4^{a}(0.2,0.7)$ & $1.0^{a}(0.6,1.7)$ & $2.2^{a}(0.9,5.4)$ \\
\hline $24 \mathrm{~h}$ & $-{ }^{b}$ & $2.6(1.0,6.5)$ & $-b$ \\
\hline $48 \mathrm{~h}$ & $1.3(0.8,2.1)$ & $4.1(1.3,13.2)$ & $8.5(1.8,40.4)$ \\
\hline 4 day & $-{ }^{b}$ & $-b^{b}$ & $16.9(3.2,88.2)$ \\
\hline 7 day & $3.2(1.3,7.7)$ & $14.6(3.2,65.8)$ & $27.5(4.9,154.5)$ \\
\hline
\end{tabular}

${ }^{a}$ Different from control value $(P<0.05)$

${ }^{b}$ Not determined.

derived by Black et al. (1985). Most studies that have employed this analysis used alkylating ligands to decrease receptor number; however, similar analyses have been applied using either pseudo-irreversible antagonists or antisense nucleotides (Chen et al., 1996; Walker et al., 1998). In the present studies, the pseudo-irreversible antagonist AM6538 reduced the fraction of available receptors for THC more than for either WIN 55,212 or AM4054. In conjunction with prior studies using more indirect methods to study THC efficacy, these data support the view that THC is a partial agonist at cannabinoid CB1 receptors (Shen and Thayer, 1999; Hruba et al., 2012; Paronis et al., 2012).

In addition to their translational value, another benefit of using pharmacological methods to decrease available receptors is the ability to track recovery of function. Accordingly, the tau values for AM4054 and THC increased progressively over time following pretreatment with AM6538 in the present studies, reflecting time-dependent recovery of the receptor population. Although absolute tau values were different in the mouse antinociceptive studies and squirrel monkey drug discrimination studies, we found qualitatively similar effects of AM6538 as an antagonist of AM4054 in both mice and squirrel monkeys. Thus, the tau values obtained in both species decrease systematically as a function of AM6538 dose and showed recovery is a function of time after administration.

In summary, the data presented here are consistent with the view that AM6538 acts as a pseudo-irreversible cannabinoid antagonist in different behavioral assays and species and that AM6538 can be effectively used to evaluate the apparent efficacy of cannabinoid full and partial agonists. A similar type of analysis may be applicable to other cannabinoid drugs and other behavioral assays. Additionally, AM6538 may be useful in future studies that require temporary reductions in cannabinoid receptor availability.

\section{Acknowledgments}

The authors thank Roger D. Spealman for comments on a previous version of the manuscript.

\section{Authorship Contributions}

Participated in research design: Paronis, Chopda, Bergman.

Conducted experiments: Chopda, Zakarian.

Contributed new reagents or analytic tools: Vemuri, Makriyannis. Performed data analysis: Paronis, Chopda.

Wrote or contributed to the writing of the manuscript: Paronis, Chopda, Bergman.

\section{References}

Banister SD, Moir M, Stuart J, Kevin RC, Wood KE, Longworth M, Wilkinson SM, Beinat C, Buchanan AS, Glass M, et al. (2015) Pharmacology of indole and indazole synthetic cannabinoid designer drugs AB-FUBINACA, ADB-FUBINACA AB-PINACA, ADB-PINACA, 5F-AB-PINACA, 5F-ADB-PINACA, ADBICA, and 5F-ADBICA. ACS Chem Neurosci 6:1546-1559.

Black JW, Leff P, Shankley NP, and Wood J (1985) An operational model of pharmacological agonism: the effect of $\mathrm{E} /[\mathrm{A}]$ curve shape on agonist dissociation constant estimation. $\mathrm{Br}$ J Pharmacol 84:561-571.

Brents LK, Gallus-Zawada A, Radominska-Pandya A, Vasiljevik T, Prisinzano TE, Fantegrossi WE, Moran JH, and Prather PL (2012) Monohydroxylated metabolites of the K2 synthetic cannabinoid JWH-073 retain intermediate to high cannabinoid 1 receptor (CB1R) affinity and exhibit neutral antagonist to partial agonist activity. Biochem Pharmacol 83:952-961.

Chen X-H, Liu-Chen LY, Tallarida RJ, Geller EB, de Riel JK, and Adler MW (1996) Use of a mu-antisense oligodeoxynucleotide as a mu opioid receptor noncompetitive antagonist in vivo. Neurochem Res 21:1363-1368.

Chopda GR, Parge V, Thakur GA, Gatley SJ, Makriyannis A, and Paronis CA (2016) Tolerance to the diuretic effects of cannabinoids and cross-tolerance to a $\mathrm{k}$-opioid agonist in THC-treated mice. J Pharmacol Exp Ther 358:334-341.

Delatte MS and Paronis CA (2008) Evaluation of cannabinoid agonists using punished responding and midazolam discrimination procedures in squirrel monkeys. Psychopharmacology (Berl) 198:521-528.

Furchgott RF and Bursztyn P (1967) Comparison of dissociation constants and of relative efficacies of selected agonists acting on parasympathetic receptors. Ann $N$ Y Acad Sci 144:882-899.

Govaerts SJ, Hermans E, and Lambert DM (2004) Comparison of cannabinoid ligands affinities and efficacies in murine tissues and in transfected cells expressing human recombinant cannabinoid receptors. Eur J Pharm Sci 23:233-243.

Hruba L, Ginsburg BC, and McMahon LR (2012) Apparent inverse relationship between cannabinoid agonist efficacy and tolerance/cross-tolerance produced by $\Delta^{9}$-tetrahydrocannabinol treatment in rhesus monkeys. J Pharmacol Exp Ther 342:843-849.

Hua T, Vemuri K, Pu M, Qu L, Han GW, Wu Y, Zhao S, Shui W, Li S, Korde A, et al. (2016) Crystal structure of the human cannabinoid receptor $\mathrm{CB}_{1}$. Cell 167:750-762.e14.

Kangas BD, Delatte MS, Vemuri VK, Thakur GA, Nikas SP, Subramanian KV, Shukla VG, Makriyannis A, and Bergman J (2013) Cannabinoid discrimination and antagonism by $\mathrm{CB}(1)$ neutral and inverse agonist antagonists. $J$ Pharmacol Exp Ther 344:561-567.

Koek W, Assié MB, Zernig G, and France CP (2000) In vivo estimates of efficacy at 5-HT1A receptors: effects of EEDQ on the ability of agonists to produce lower-lip retraction in rats. Psychopharmacology (Berl) 149:377-387.

Laprairie RB, Kulkarni PM, Deschamps JR, Kelly MEM, Janero DR, Cascio MG, Stevenson LA, Pertwee RG, Kenakin TP, Denovan-Wright EM, et al. (2017) Enantiospecific allosteric modulation of cannabinoid 1 receptor. ACS Chem Neurosci 8:1188-1203.

Leff $P$ and Dougall IG (1989) Estimation of affinities and efficacies for kappa-receptor agonists in guinea-pig ileum. Br J Pharmacol 96:702-706.

Liguori A, Morse WH, and Bergman J (1996) Respiratory effects of opioid full and partial agonists in rhesus monkeys. J Pharmacol Exp Ther 277:462-472.

Little PJ, Compton DR, Johnson MR, Melvin LS, and Martin BR (1988) Pharmacology and stereoselectivity of structurally novel cannabinoids in mice. $J$ Pharmacol Exp Ther 247:1046-1051.

Madia PA, Navani DM, and Yoburn BC (2012) [(35)S]GTP $\gamma$ S binding and opioid tolerance and efficacy in mouse spinal cord. Pharmacol Biochem Behav 101: $155-165$

Marshell R, Kearney-Ramos T, Brents LK, Hyatt WS, Tai S, Prather PL, and Fantegrossi WE (2014) In vivo effects of synthetic cannabinoids JWH-018 and JWH-073 and phytocannabinoid $\triangle 9$-THC in mice: inhalation versus intraperitoneal injection. Pharmacol Biochem Behav 124:40-47.

Nickolls SA, Waterfield A, Williams RE, and Kinloch RA (2011) Understanding the effect of different assay formats on agonist parameters: a study using the $\mu$-opioid receptor. J Biomol Screen 16:706-716.

Nutt D, King LA, Saulsbury W, and Blakemore C (2007) Development of a rational scale to assess the harm of drugs of potential misuse. Lancet 369:1047-1053.

Paronis CA and Holtzman SG (1992) Development of tolerance to the analgesic activity of mu agonists after continuous infusion of morphine, meperidine or fentanyl in rats. $J$ Pharmacol Exp Ther 262:1-9. 
Paronis CA, Nikas SP, Shukla VG, and Makriyannis A (2012) $\Delta(9)$-Tetrahydrocannabinol acts as a partial agonist/antagonist in mice. Behav Pharmacol 23:802-805.

Petitet F, Jeantaud B, Bertrand P, and Imperato A (1999) Cannabinoid penetration into mouse brain as determined by ex vivo binding. Eur J Pharmacol 374:417-421.

Rinaldi-Carmona M, Barth F, Héaulme M, Shire D, Calandra B, Congy C, Martinez S, Maruani J, Néliat G, Caput D, et al. (1994) SR141716A, a potent and selective antagonist of the brain cannabinoid receptor. FEBS Lett 350:240-244.

Rohrer DK and Kobilka BK (1998) G protein-coupled receptors: functional and mechanistic insights through altered gene expression. Physiol Rev 78:35-52.

Shen M and Thayer SA (1999) Delta9-tetrahydrocannabinol acts as a partial agonist to modulate glutamatergic synaptic transmission between rat hippocampal neurons in culture. Mol Pharmacol 55:8-13.

Tai S, Hyatt WS, Gu C, Franks LN, Vasiljevik T, Brents LK, Prather PL and Fantegrossi WE (2015) Repeated administration of phytocannabinoid $\Delta(9)$-THC or synthetic cannabinoids JWH-018 and JWH-073 induces tolerance to hypothermia but not locomotor suppression in mice, and reduces CB1 receptor expression and function in a brain region-specific manner. Pharmacol Res 102: $22-32$.

Walker EA, Richardson TM, and Young AM (1997) Tolerance and cross-tolerance to morphine-like stimulus effects of $\mu$ opioids in rats. Psychopharmacology (Berl) 133: $17-28$.

Walker EA, Zernig G, and Young AM (1998) In vivo apparent affinity and efficacy estimates for $\mu$ opiates in a rat tail-withdrawal assay. Psychopharmacology (Berl) 136:15-23.

Address correspondence to: Dr. Carol A. Paronis, Preclinical Pharmacology Program, McLean Hospital, 115 Mill St., Belmont, MA 02478. E-mail: cparonis@mclean.harvard.edu 